\title{
PHYTOSYNTHESIS AND CHARACTERIZATION OF IRON NANOCOMPOSITES BY IRVINGIA GABONENSIS (OGBONO) AQUEOUS AND ETHANOL LEAF EXTRACTS
}

\author{
Ebong Sifon Emem ${ }^{1}$, Adowei Pereware ${ }^{*}{ }^{\square}$, Obuzor Gloria Ukalina ${ }^{3}$ \\ $1, * 2,3$ Department of Pure and Industrial Chemistry, Faculty of Science, University of Port Harcourt, \\ Choba, Nigeria
}

DOI: https://doi.org/10.29121/granthaalayah.v8.i5.2020.324

Article Type: Research Article

Article Citation: Ebong Sifon Emem, Adowei, Pereware, and Obuzor, Gloria Ukalina. (2020). PHYTOSYNTHESIS AND CHARACTERIZATION OF IRON NANOCOMPOSITES BY IRVINGIA GABONENSIS (OGBONO) AQUEOUS AND ETHANOL LEAF EXTRACTS. International Journal of Research GRANTHAALAYAH, 8(5), 256-265. https://doi.org/10.29121/granthaa layah.v8.i5.2020.324

Received Date: 17 May 2020

Accepted Date: 31 May 2020

Keywords:

Phytosynthesis

Nano-Composite

Irvingia Gabonensis

Ogbono

\section{ABSTRACT}

The need for emerging materials based on nano-composites from green plants, or non-useful materials for adsorption process is on the increase. The objective of this research was to evaluate the phytosynthesis and characterization of iron nano-composites (Fe.NCs) formed by aqueous and ethanol extracts of Irvingia gabonensis (Ogbono) tree leaves. The composites were characterized by visual observation, Fourier transform infrared spectroscopy (FTIR) and scanning electron microscopy (SEM). Visual observation of the iron oxide nano-composites synthesized was confirmed by change in colour from yellow to brown within minutes of formation. The FTIR characterization showed that, phenolic groups were involved in the phytosynthesis of the iron nano-composites with the presence of $-\mathrm{OH}$ and $-\mathrm{NH}$ groups at $3348.54 \mathrm{~cm}-1$ and $-\mathrm{C}-\mathrm{N}-$ group at $1635.69 \mathrm{~cm}-1$ for aqueous extract and broad band of $-\mathrm{OH}$ and $-\mathrm{NH}$ stretch at $3363.97 \mathrm{~cm}-1$ and $-\mathrm{C}-\mathrm{H}$-stretch at $2978-2901.04 \mathrm{~cm}-1$ attributed to alkanes in alcohol extract. There was also $-\mathrm{OH}$ stretch at $2885.60 \mathrm{~cm}-1$ and Fe-O group at $671.25 \mathrm{~cm}-1$ in Fe. NCs with Fe-O stretch observed at $583.33 \mathrm{~cm}-1$ in I. gabonensis iron nano-composite. Cube-like structures, irregular shapes and sizes with individual, spherical particles forming aggregates and chains were revealed by the SEM micrographs, these are recognized attributes of strong magnetic properties of iron. The particle sizes are 30 and $45 \mathrm{~nm}$ for aqueous and alcohol extracts respectively, which could provide large surface area for contaminant adsorption. Conclusively, photosynthesis of Fe. NCs using water and ethanol extracts of I. gabonensis (Ogbono leaves) could be an effective one-step pathway for nanocomposite production from eco-friendly, safe and less toxic green plant material.

\section{INTRODUCTION}

Nanoparticles research is an important aspect due to its innumerable applications. Nanoparticles have expressed significant advances owing to wide range of applications in the field of bio-medical (Gupta and Gupta, 2005), sensors (Jagajjanani and Paria, 2013), catalysts (Shahwan et al., 2011), electronics (Frey and Sun, 2009), photocatalysis (Zhang et al., 2012) and adsorption (Al-Gorair, 2019). Nanoparticle may be synthesized by a bottomup approach where atoms and molecules are assembled to form nanomaterials of required size and shape by

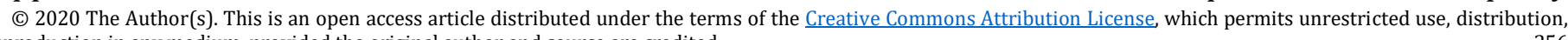
and reproduction in any medium, provided the original author and source are credited. 
Ebong Sifon Emem, Adowei, Pereware, and Obuzor, Gloria Ukalina

controlled deposition or reaction parameters and by a top-down approach where the reverse mechanism is employed by removing atoms and molecules from the bulk material to obtain the desired nanoparticle.

Biosynthesis of nanoparticles is a special thoughtful procedure of bottom-up approach where the foremost process is redox reaction (Krishnaveni et al., 2018; Naik, et al., 2002). The microbial enzymes or the plant phytochemicals with anti-oxidant or reducing properties are usually responsible for reduction of metal compounds into their respective nanoparticles (Hedaginal and Taranath, 2016). This technique is described as green synthesis and it provides advancement over chemical and physical method due to its cost effectiveness, environment friendliness, ease of synthesis scaled-up and without need for to use high pressure, energy, temperature and toxic chemicals (Ahmad and Sastry, 2004). Green synthesis offers better manipulation, control over crystal growth and their stabilization (Ojha et al., 2013). Recently, great efforts were made to use green and eco-friendly method for synthesis of nanosized materials. These efforts include the use of plant or fruit extracts as surfactant (Zahra, 2014). The plant extracts release a variety of metabolites including carbohydrates, polysaccharides, phenols, amino acids, and vitamins, which can act as capping agents, reducing agents, stabilizing and chelating agents. The use of plant extracts in the synthesis can influence the size, the shape, and the morphology of the nanoparticles. According to Laokul et al., (2011) and Varma, (2012), plant-based nanoparticles generate materials with high dispersity, high stability, and narrow size distribution.

Beside plants, various organisms may act as clean, eco-friendly and sustainable precursors to generate stable and well functionalised nanoparticles. These may include bacteria, actinomycetes, fungi, yeast, viruses, etc. (Mandal et al., 2006; Jebali et al., 2011). Thus, it is crucial to explore a more reliable and sustainable process for the synthesis of nanoparticles. Biosynthesis of nanoparticles is advantageous over physical and chemical methods as it is a relatively cheap, eco-friendly, and non-toxic substitute to chemical and physical method (Mandal et al., 2006). Also plant mediated synthesis of nanoparticles is a green chemistry technique that integrates nanotechnology and plant biotechnology (Virkutyte and Varma, 2013). Virkutyte and Varma, 2013). The desire to synthesize nanoparticles using natural materials with less expensive and less harmful effects has been on the increase in modern times. However, several plants and plant materials in Nigeria have not been fully explored in their capacity as precursor for nanoparticle synthesis. The leaves of the Ogbono (Irvingia gabonensis) tree currently have no economic use as the fruit is in high demand in Nigeria but its leaves constitute waste problems as large amount of leaves are shed daily. Therefore, the objective of this paper is to report the phytosynthesis and characterization of iron nanocomposites of aqueous and ethanol leaf extracts of Irvingia gabonensis (Ogbono) leaves.

\section{MATERIALS AND METHODS}

\subsection{MATERIALS}

Chemical reagents used were of analytical grade and acquired from representatives of Merck and Aldrich.

Sample Collection: Fresh leaves of Irvingia gabonensis (Ogbono) were collected from Delta Park University of Port Harcourt Rivers State. Taxonomical identification and authentication were carried out at the University of Port Harcourt Herbarium.

Sample Preparation: Fresh leaves were plucked from Irvingia gabonensis (Ogbono) tree plants and washed 4 times with tap water and finally two times with distilled water to remove dirt, bird droppings and other impurities. The washed leaves were shade dried for 5 hours to remove residual moisture. Dried leaves were grounded to powdery form and kept for further use as samples.

Aqueous Extraction of Irvingia gabonensis (Ogbono) leaves: To finely powder dried sample (30.0 g) in a 250 $\mathrm{ml}$ conical flask, $150 \mathrm{ml}$ distilled water was added and placed in a water bath. The mixture was allowed to boil at $60^{\circ} \mathrm{C}$ for 20 minutes. The aqueous plant extract was filtered with Whatman No. 1 filter paper and after filtration was stored in a refrigerator at $4^{\circ} \mathrm{C}$ for characterization and further use. The filtrate $(100 \mathrm{ml})$ was used as reducing agent and stabilizer for nanoparticles synthesis (Plate 1). 
Phytosynthesis and Characterization of Iron Nanocomposites by Irvingia Gabonensis (Ogbono) Aqueous and

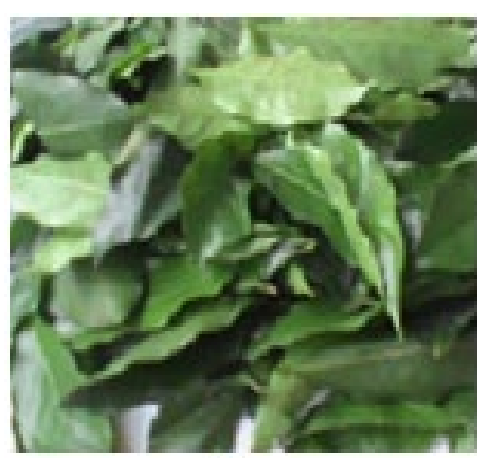

$\mathbf{a}$
Ethanol Leaf Extracts
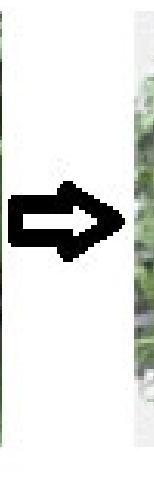

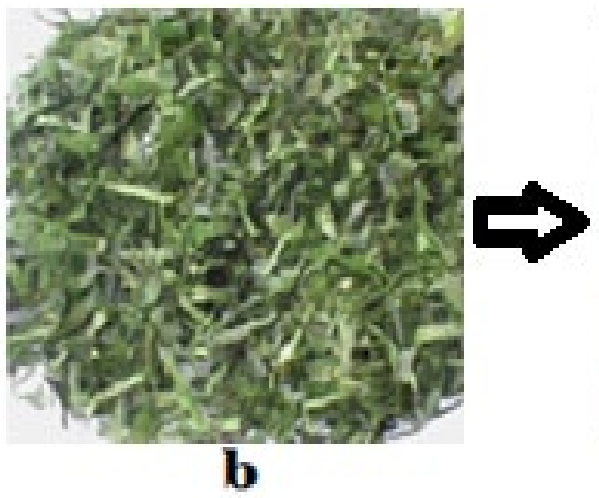

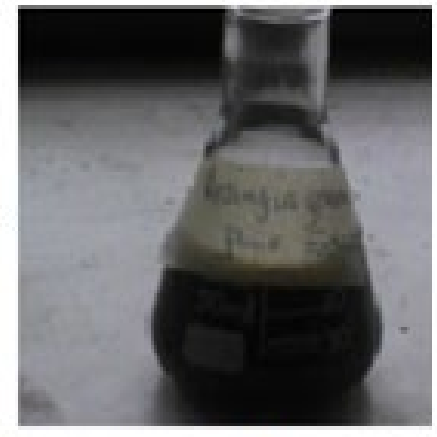

C

Plate 1: Preparation of Irvingia gabonensis (Ogbono) leaves extract: (a) fresh Irvingia gabonensis (Ogbono) leaves; (b) finely chopped Irvingia gabonensis (Ogbono) leaves; (c) aqueous leaves extract

\subsection{SYNTHESIS OF ZEROVALENT IRON NANOPARTICLES (NZVI)}

In a fume cupboard, to $0.05 \mathrm{M} \mathrm{FeSO}_{4} \cdot 7 \mathrm{H}_{2} \mathrm{O}(250 \mathrm{ml})$ in a 3-neck round bottom flask $(500 \mathrm{ml})$ placed on a magnetic stirrer was added $250 \mathrm{ml} 0.05 \mathrm{M} \mathrm{NaBH}_{4}$ in a drop wise fashion with continuous stirring at room temperature and black precipitates were observed instantly with the evolution of hydrogen gas. At the complete addition of excess $\mathrm{NaBH}_{4}$ solution, the mixture was stirred for an additional 1 hour.

The precipitates were collected by filtration with whatman filter paper No.1 and washed three times with distilled water and with absolute ethanol twice. Washed precipitates were oven dried at $50{ }^{\circ} \mathrm{C}$ for 12 hours. The precipitate (3.86 g) was stored in labeled sterile bottle for characterization and adsorption studies (Plate 2)
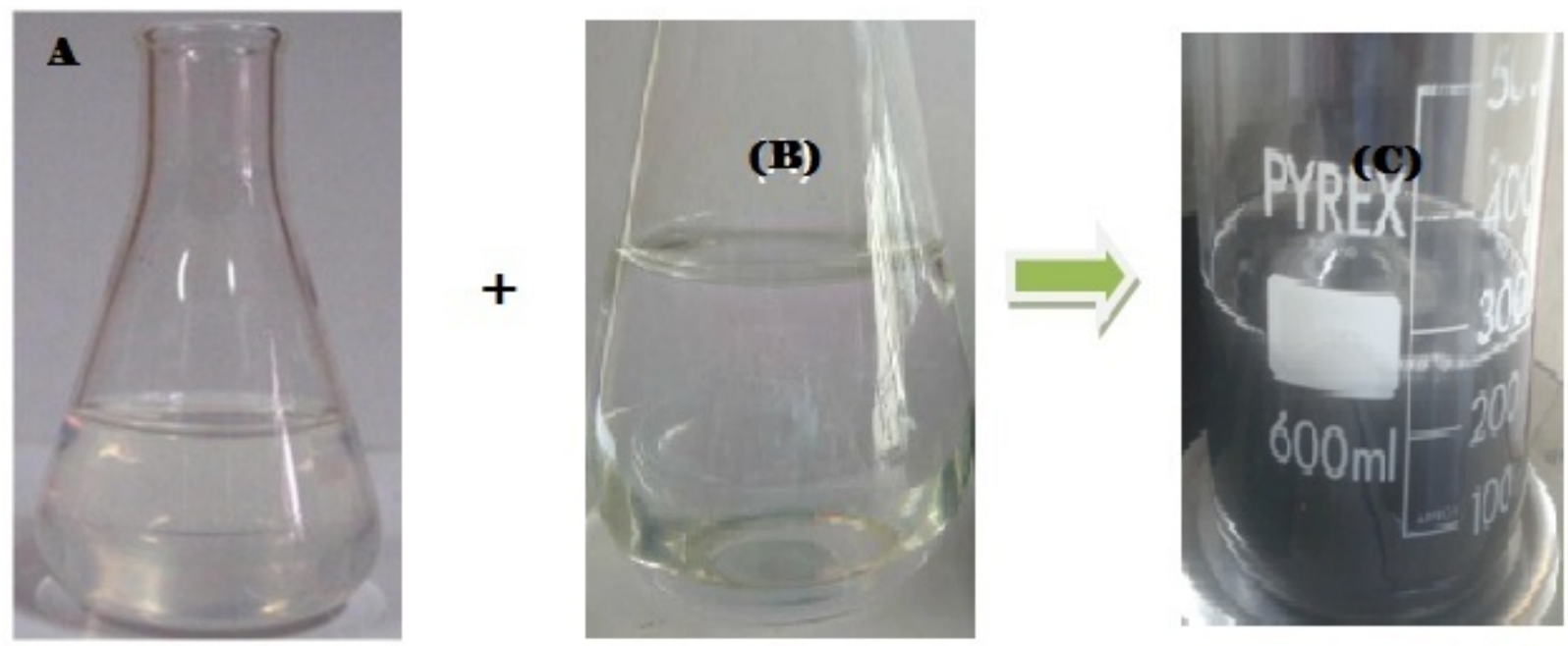

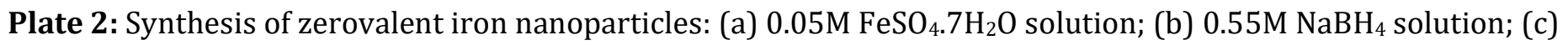
zerovalent iron nanoparticles solution

Phytosynthesis of Irvingia gabonensis (Ogbono) iron nanoparticles (Ig-nZVI): For reduction of iron ions, $10 \mathrm{ml}$ of Irvingia gabonensis (Ogbono) leaf extract was added in drops to $90 \mathrm{ml}$ of $0.05 \mathrm{M} \mathrm{FeSO}_{4} .7 \mathrm{H}_{2} \mathrm{O}$ solution in a $250 \mathrm{ml}$ conical flask on a magnetic stirrer. On addition of the first 4 drops of the plant extract the clear iron (II) solution immediately turned black. This indicated the synthesis of Iron nanoparticles (Shahwan et al., 2011). Concurrently, the reaction mixture was adjusted to $\mathrm{pH} 8$ by adding in drops $1.0 \mathrm{M} \mathrm{NaOH}$ solution. The reaction mixture was further stirred for 1 hour and later incubated at $60^{\circ} \mathrm{C}$ in a water bath for 20 minutes to precipitate the Ig-nZVI. The reaction mixture was filtered with a whatman filter paper No.1 to obtain Ig-nZVI. The obtained Ig-nZVI was washed with distilled water 3 times and finally with absolute ethanol 2 times. The filtrate obtained was kept in the oven at $50^{\circ} \mathrm{C}$ for 12 hours. The dried sample was collected and stored in a labeled sterile bottle for characterization (Plate 3 ). 


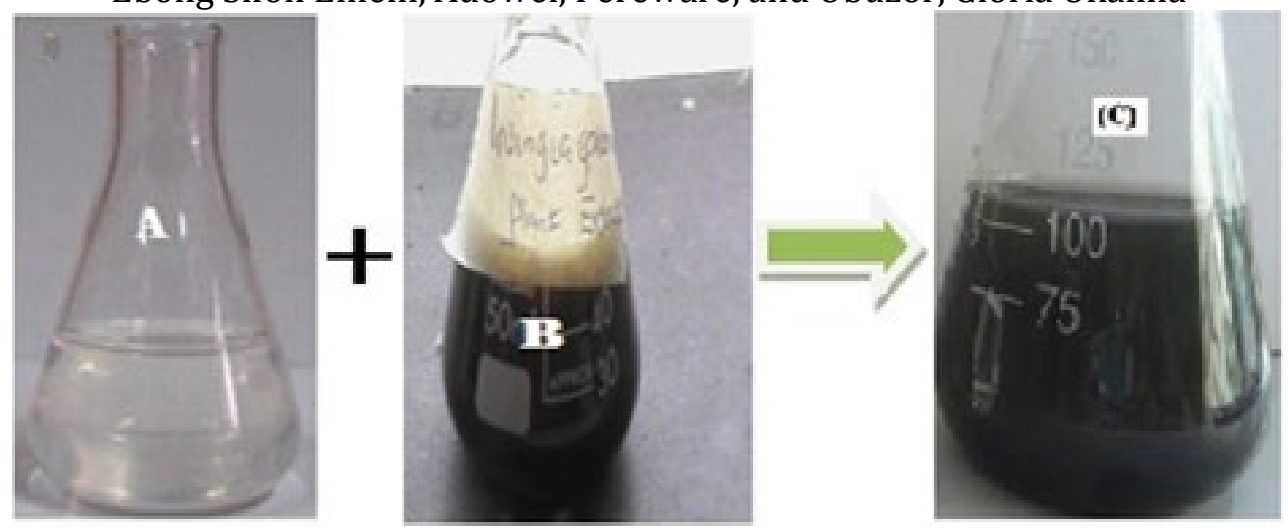

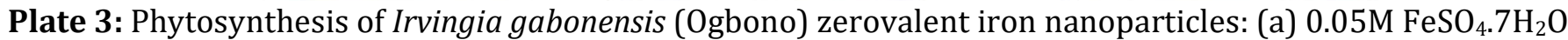
solution; (b) aqueous Irvingia gabonensis (Ogbono) leaves extract; (c) Irvingia gabonensis (Ogbono) stabilized zerovalent iron nanoparticles solution.

The synthesis of zerovalent iron nanoparticles was achieved by the reaction of sodium borohydride solution with iron II sulfate heptahydrate solution.

$$
4 \mathrm{~F}^{2+}(\mathrm{aq})+3 \mathrm{BH}_{4}^{-}+9 \mathrm{H}_{2} \mathrm{O} \rightarrow 4 \mathrm{~F}^{0}(\mathrm{~s}) \downarrow+3 \mathrm{H}_{2} \mathrm{BO}_{3}+12 \mathrm{H}^{+} \mathrm{aq}+6 \mathrm{H}_{2(\mathrm{aq})} \uparrow
$$

The reaction of iron II sulfate heptahydrate solution with I. gabonensis (Ogbono) aqueous and ethanol leaves extract gave Ig-nZVI.

Characterization by Fourier Transform Infrared (FTIR) Spectroscopy: FTIR analysis of the dried samples was carried out through the potassium bromide (KBr) pellet (FTIR grade) method in 1:100 ratio and spectrum was recorded using Jasco FT/IR-6300 Fourier transform infrared spectrometer equipped with JASCO IRT-7000 Intron Infrared Microscope using transmittance mode operating at a resolution of $4 \mathrm{~cm}^{-1} .2 .10 \mathrm{Xrd}$ analysis.

Characterization by Scanning Electron Microscopy (SEM) analysis: The synthesized samples were characterized for surface morphology by scanning electron microscopy (SEM) using JEOL/JSM-5610 NE Instrument model, and also the chemical composition of samples was estimated by EDAX spectroscopy technique.

\section{RESULTS AND DISCUSSION}

Visual Observations for Nanoparticles Syntheses: A change in the colour of the reaction medium from a clear solution to a black solution was observed within few seconds this was as a result of reduction of Iron II ion ( $\left.\mathrm{Fe}^{2+}\right)$ to zerovalent iron $\left(\mathrm{Fe}^{0}\right)$. The black colour observed could be attributed to the excitation of surface Plasmon resonance of the metal nanoparticles (Fang et al., 2005). Results from the present study regarding color changes of the prepared nanoparticles using Irvingia gabonensis (Ogbono) extracts are shown in plates 1 and 2 respectively. There were changes in color in minutes from yellow to black and the density and intensity of precipitate increased gradually to reach the highest darkness and density of precipitate after 24 hours of mixing extracts with the ferric and ferrous mixture. The best appearance of nanoparticles biosynthesized was in the flask containing ferrous and ferric mixture with extract in $1: 2(\mathrm{v} / \mathrm{v})$ ratio. The produced particles were crystallized and precipitate clearly at the bottom of the flask. The change in color from brown to black tack indicated formation of magnetite particles, the most predominant step in formation of magnetite is reduction of ferric or ferrous to oxide to form $\mathrm{Fe} 2 \mathrm{O} 3$ or $\mathrm{Fe} 304$. Irvingia gabonensis (Ogbono) extract containing a phytochemical component with high reducing capability such as flavonoids, caffeine acid, and other phenolic compounds (Gulcin et al., 2010).

Characterization of the nanoparticles using FTIR: In this study FTIR analysis was confirmed in order to evaluate the functional groups on Irvingia gabonensis (Ogbono). The FTIR spectrum (Figure 1) for showed possible groups present in I. gabonensis (Ogbono) leaves aqueous extract with characteristics absorption peaks $\left(\mathrm{cm}^{-1}\right)$ at $3348.54,2114.05$ and 1635.69 (Table 1). The sharp and broad band at $3348.54 \mathrm{~cm}^{-1}$ could be attributed to N-H and $\mathrm{O}-\mathrm{H}$ stretching of amines and polymeric $\mathrm{OH}$ (alcohols, polyphenols and water). The $\mathrm{N}=\mathrm{C}=\mathrm{S}$ stretching mode of 
Phytosynthesis and Characterization of Iron Nanocomposites by Irvingia Gabonensis (Ogbono) Aqueous and Ethanol Leaf Extracts

isothiocyanate displayed weak absorption at $2114.05 \mathrm{~cm}^{-1}$. The absorption at $1635.69 \mathrm{~cm}^{-1}$ was probably due to strong C-N stretching of amines. The FTIR spectrum (Figure 2) of I. gabonensis (Ogbono) leaves ethanol extract displayed various characteristic absorption peaks $\left(\mathrm{cm}^{-1}\right)$ at 3363.97, 2978.19, 2901.4, 2345.52, 1658.84, 1411.94, 1057.03 and 856.42 as shown in Table 2. The absorption band at $3363.97 \mathrm{~cm}^{-1}$ could be ascribed to $\mathrm{N}-\mathrm{H}$ and $\mathrm{O}-\mathrm{H}$ stretching of amines and polymeric $\mathrm{OH}$ of alcohols. There were sharp and variable peaks at 2978.19-2901.04 $\mathrm{cm}^{-1}$ which was probably due C-H stretching of alkanes. The absorption bands at $2345.52 \mathrm{~cm}^{-1}$ and $1658.84 \mathrm{~cm}^{-1}$ were $^{-1}$ ascribed to $\mathrm{O}=\mathrm{C}=\mathrm{O}$ and $\mathrm{C}=\mathrm{C}$ vibration stretching of carbon dioxide, alkanes and sulphate. The intense sharp band at $1057.03 \mathrm{~cm}^{-1}$ could be attributed to strong C-O stretching of primary alcohol.

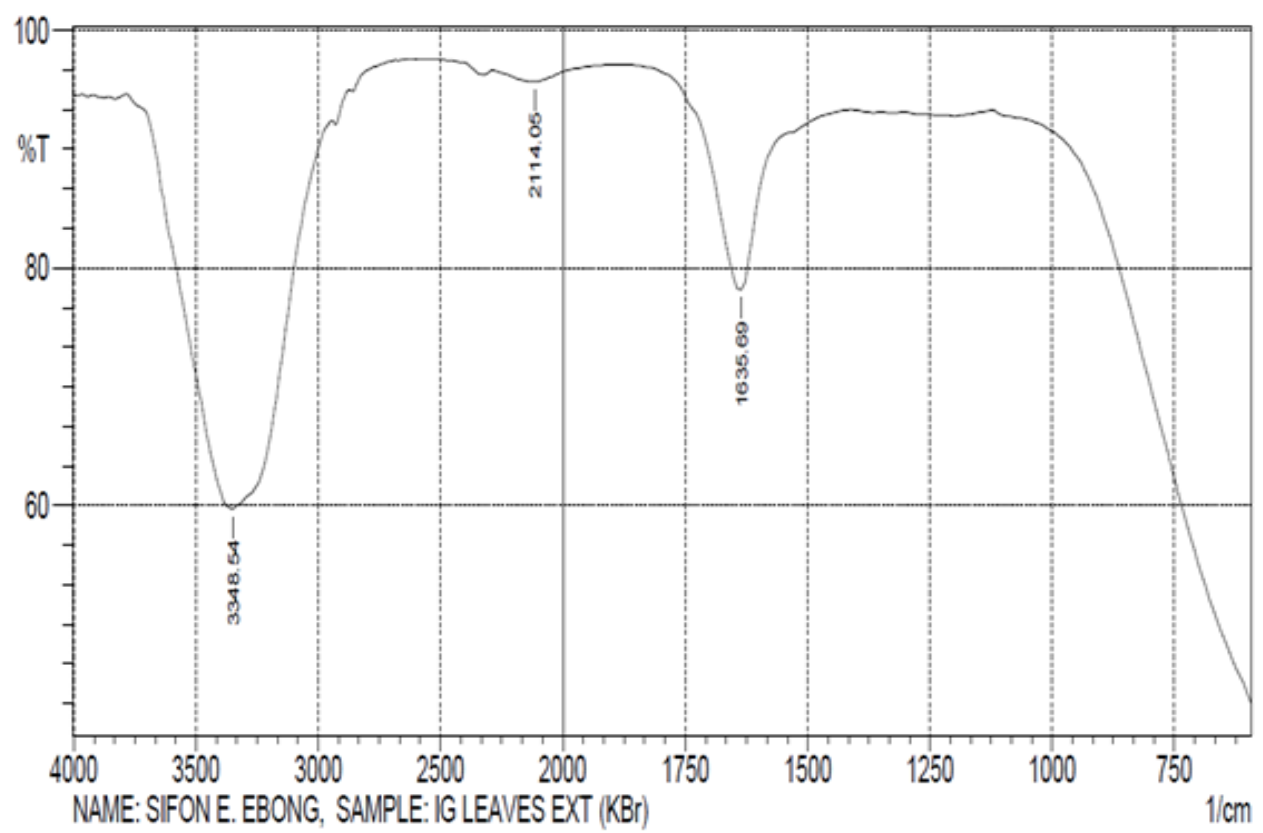

Figure 1: FTIR Spectrum of Irvingia gabonensis (Ogbono) aqueous Leaves Extract

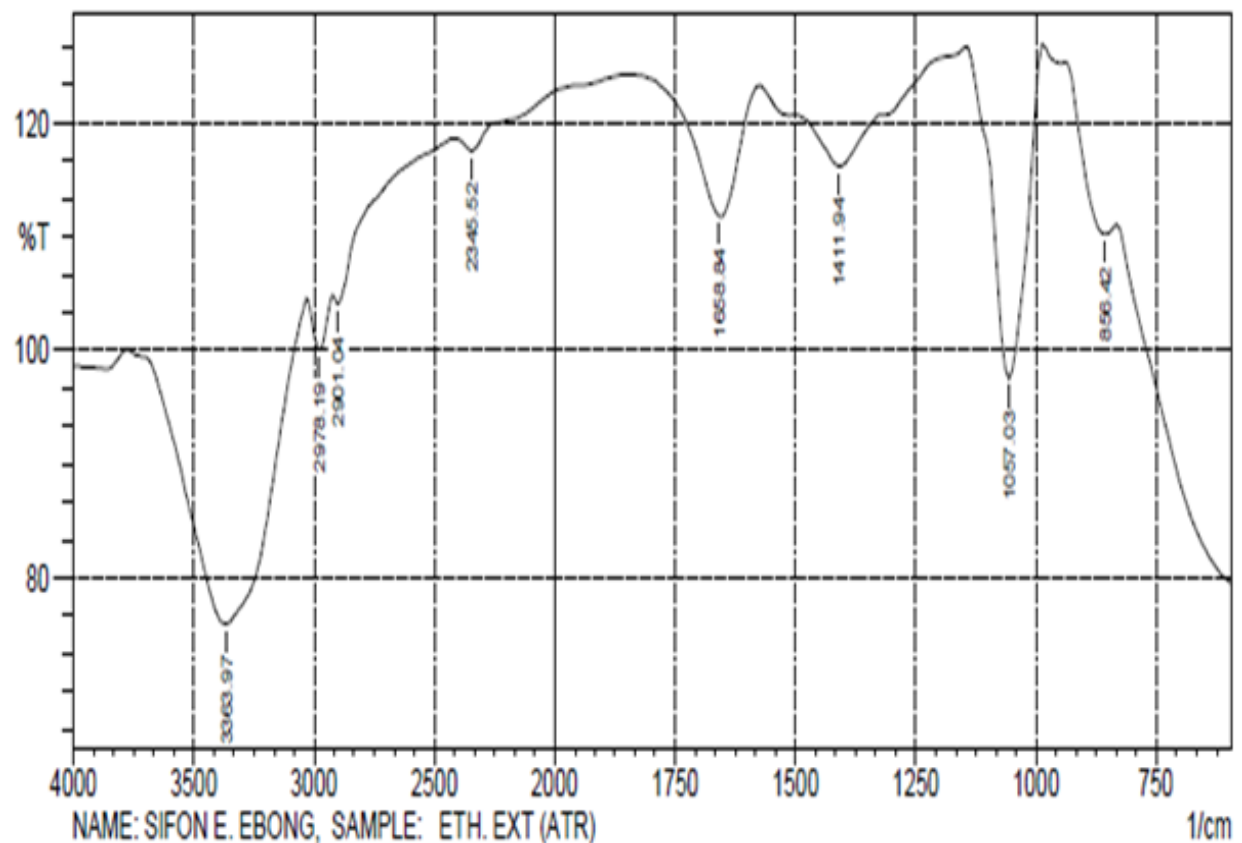

Figure 2: FTIR Spectrum of Irvingia gabonensis (Ogbono) ethanol Leaves Extract 
Ebong Sifon Emem, Adowei, Pereware, and Obuzor, Gloria Ukalina

Table 1: FTIR absorption peaks values and their functional groups for Irvingia gabonensis (Ogbono) leaves aqueous extract

\begin{tabular}{|c|c|c|}
\hline Serial Number & Absorption Peak $\left(\mathrm{cm}^{-1}\right)$ & Functional Groups \\
\hline 1 & 3348.54 & N-H and OH stretch \\
\hline 2 & 2114.05 & $\mathrm{~N}=\mathrm{C}=\mathrm{S}$ Isothiocyanate stretch \\
\hline 3 & 1635.69 & C-N Amines stretch \\
\hline
\end{tabular}

Table 2: FTIR absorption peaks values and their functional groups for Irvigia gabonensis (Ogbono) leaves ethanol extract

\begin{tabular}{|c|c|c|}
\hline Serial Number & Absorption Peak $\left(\mathrm{cm}^{-1}\right)$ & Functional Groups \\
\hline 1 & 3363.97 & N-H and OH stretch \\
\hline 2 & 2978.19 & C-H Alkanes stretching \\
\hline 3 & 2901.04 & C-H Alkanes stretching \\
\hline 4 & 2345.52 & O=C=O Carbon Dioxide stretch \\
\hline 5 & 1658.84 & C=C group or aromatic rings \\
\hline 6 & 1057.03 & C-O stretching \\
\hline
\end{tabular}

The FTIR spectrum (Figure 3) of nZVI displayed various absorption peaks $\left(\mathrm{cm}^{-1}\right)$ at $3726.60,2885.60,2823.88$, $2345.52,1689.70,1527.67,1404.22,987.59,895$ and 671.25 as shown in Table 3 . The bands at $3726.60 \mathrm{~cm}^{-1}$, $2885.60 \mathrm{~cm}^{-1}$ and $2823.88 \mathrm{~cm}^{-1}$ were ascribed to stretching vibrations of $0-\mathrm{H}$ group in water on the nanoparticles. The formation of nZVI was characterized by an absorption band at $671.25 \mathrm{~cm}^{-1}$ which corresponded to the Fe-O bond in magnetite. These peak values almost agree with the value reported by Kim et al. (2007).

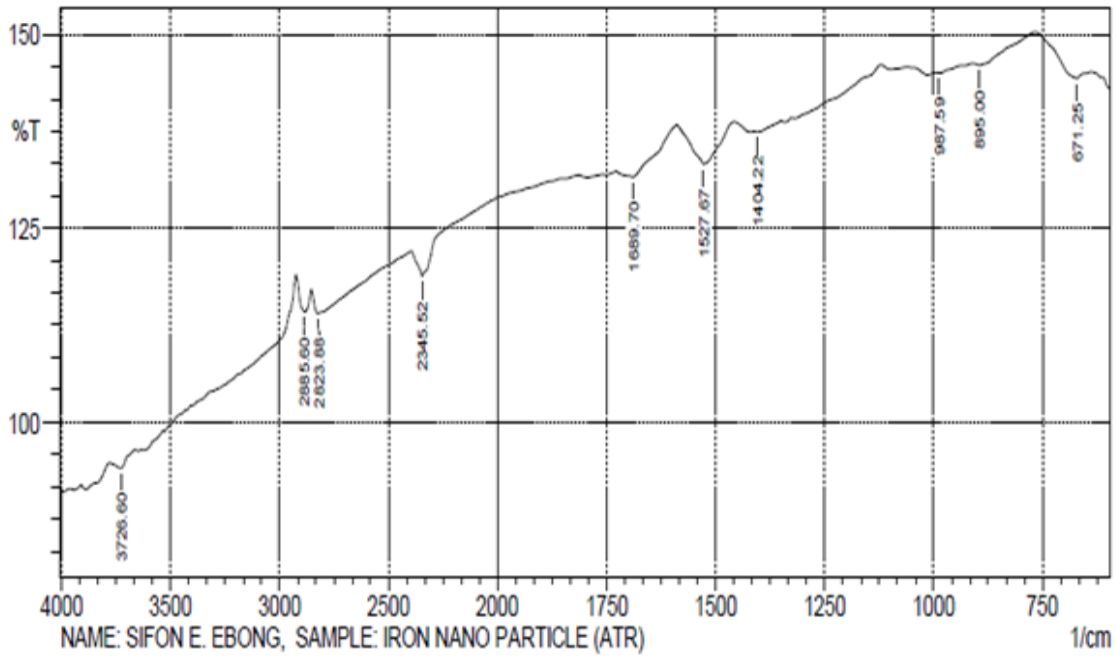

Figure 3: FTIR Spectrum of nZVI

Table 3: FTIR absorption peaks values and their functional groups for nZVI

\begin{tabular}{|c|c|c|}
\hline Serial Number & Absorption Peak $\left(\mathrm{cm}^{-1}\right)$ & Functional Groups \\
\hline 1 & 3726.60 & N-H and OH stretch \\
\hline 2 & 2885.60 & C-H Alkanes stretching \\
\hline 3 & 2823.88 & C-H Alkanes stretching \\
\hline 4 & 671.25 & Fe-O bond in magnetite \\
\hline
\end{tabular}

The absorption signals $\left(\mathrm{cm}^{-1}\right)$ at 3857.76, 3726.60 and 3618.58 in Ig-nZVI (Table 4) are due to stretching vibrations of $\mathrm{O}-\mathrm{H}$ groups in water, alcohol and phenols. The band at $1404.22 \mathrm{~cm}^{-1}$ showed the C-C groups derived from aromatic rings that are present in the I. gabonensis leaf extract and also the peaks at $1705.13 \mathrm{~cm}^{-1}$ and $1195.91 \mathrm{~cm}^{-1}$ are attributed to the conjugated carbonyl $(. C=0)$ group stretching vibration in polyphenols, and this was ascribed to the binding of a $\mathrm{C}=0$ group with the nanoparticles. The band at $1064.74 \mathrm{~cm}^{-1}$ was ascribed to the C$\mathrm{N}$ Stretching vibration of amines. The formation of Ig-nZVI was characterized by an absorption band at $583.33 \mathrm{~cm}^{-1}$ 
Phytosynthesis and Characterization of Iron Nanocomposites by Irvingia Gabonensis (Ogbono) Aqueous and Ethanol Leaf Extracts

which corresponded to the Fe-O bond in magnetite. This peak value almost goes with the value reported by Kim et al. (2007). As seen from the FTIR spectrum (Figure 4) and the result of Ig-nZVI (Table 4) it seems that the soluble elements present in I. gabonensis leaf extract have the presence of higher percentage of molecules of phenolic groups and amines. Thus, the result suggests that the biological molecules (phenolic group and free amine groups) could most likely act as a capping/reducing agent, which prevents the aggregation of nanoparticles in solution while forming and stabilizing Ig-nZVI (Gole et al., 2001; Raut et al., 2010; Singh et al., 2013; Kannan et al., 2013).

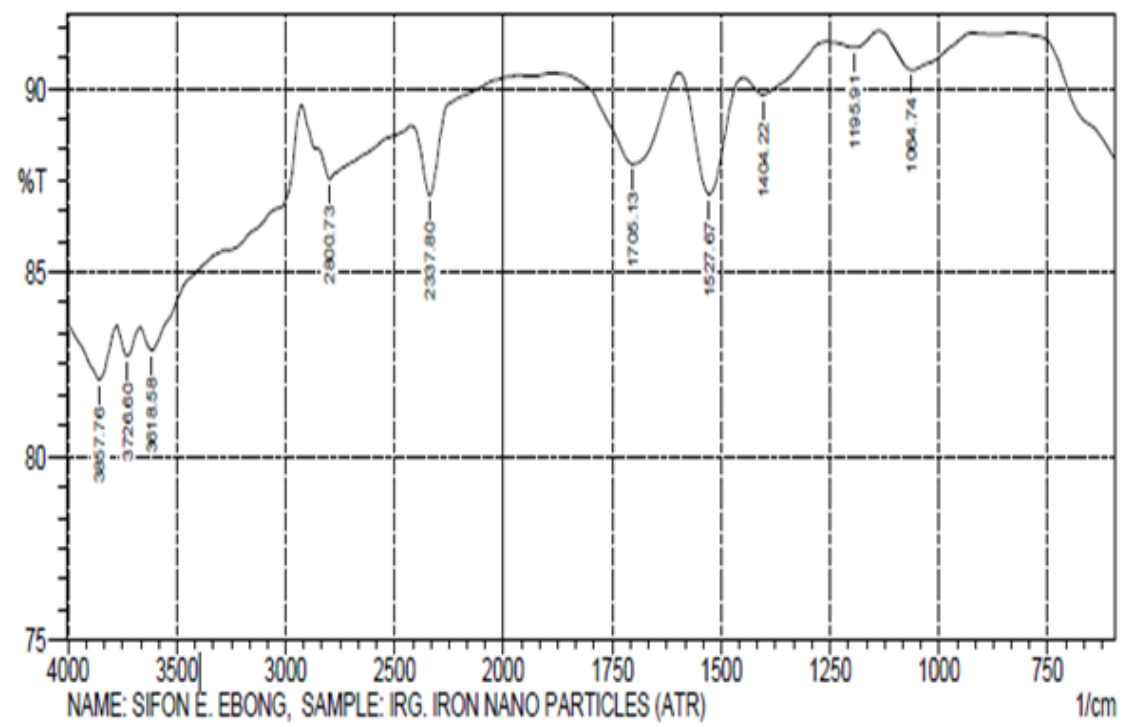

Figure 4: FTIR Spectrum of Ig-nZVI

Table 4: FTIR absorption peaks values and their functional groups for Ig-nZVI

\begin{tabular}{|c|c|c|}
\hline Serial Number & Absorption Peak $\left(\mathrm{cm}^{-1}\right)$ & Functional Groups \\
\hline 1 & 3857.76 & O-H and N-H stretch \\
\hline 2 & 3726.60 & O-H and N-H stretch \\
\hline 3 & 3618.58 & O-H and N-H stretch \\
\hline 4 & 1705.13 & C=O conjugated carbonyl stretching \\
\hline 5 & 1195.91 & C=0 conjugated carbonyl stretching \\
\hline 6 & 1064.74 & C-N Amines stretch \\
\hline 7 & 583.33 & Fe-O bond in Magnetite \\
\hline
\end{tabular}

Characterization of the nanoparticles using SEM Analysis: Scanning Electron Microscopy (SEM) image is very important to identify the shapes of the nanoparticles formed. SEM is able to provide images of threedimensional objects because in its normal mode of operation it records not the electrons passing thorough the specimen but the secondary electrons that are released from the sample by the electron beam impinging on it. SEM micrographs of Ig-nZVI (Figure 5) showed that most of the nanoparticles have cuboidal morphology while some were present with irregular shapes and sizes. This variation in nanoparticles size may be related to strong magnetic properties of iron itself. Similarly, SEM images of nZVI particles as seen in Figure 6 indicated that nZVI is composed of individual, spherical particles that form aggregates and chains. This small nZVI particle size provides a larger surface area for contaminant adsorption. Similar result was obtained by Boparai et al. (2011).

Scanning electron microscopic images were employed to analysis the morphology and size of nanoparticles that formed in presented study. The examined particles were agglomerated, the size morphology is irregular, the magnetite nanoparticles shape showed cubic shape particles and different particles size due to bioreduction of iron salts by propolis extract. this outcome can be explained by the fact that the polyphenol concentration in propolis extract plays roles in formation final structure and particles size of these green synthesis magnetite nanoparticles (Mahdavi et al., 2013). in present study the particles size in magnetite nanoparticles synthesis les from mixture ferric and ferrous is smaller than particle size which synthesis from FeSO4 that its indicator to the propolis extract 
Ebong Sifon Emem, Adowei, Pereware, and Obuzor, Gloria Ukalina reducing the mixture more than FeSO4, the iron oxide NPs formed by mixture is high activity from FeSO4NP because decrease in particles size and increase in surface area.
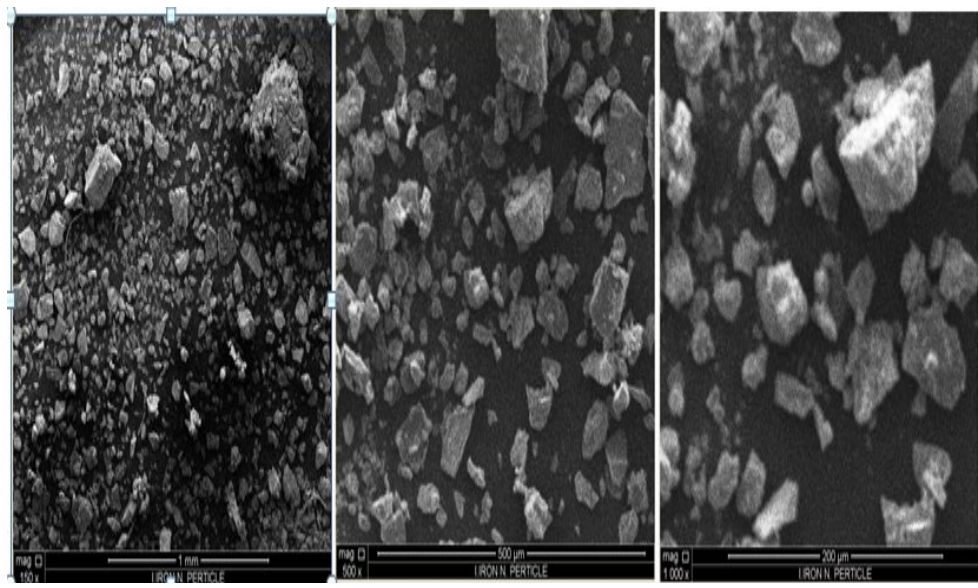

Figure 5: SEM Micrographs of Ig-nZVI

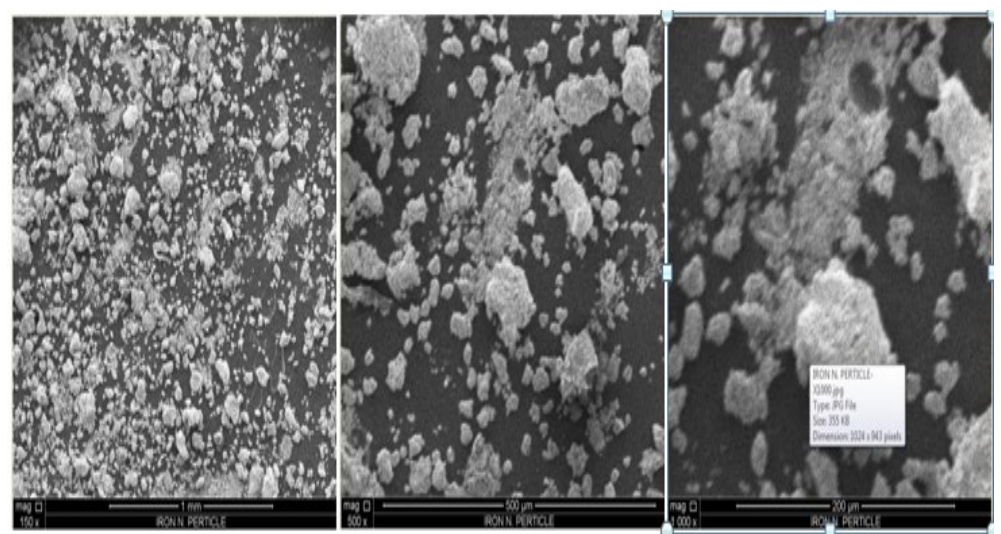

Figure 6: SEM Micrographs of nZVI

\section{CONCLUSION}

Conclusively, photosynthesis of Fe.NCs using metal salts alongside water and ethanol extracts of I. gabonensis (Ogbono) could be an effective one-step green alternative to the production of zerovalent iron nanoparticle from sodium borohydride and metal salt for adsorption process.

\section{SOURCES OF FUNDING}

None.

\section{CONFLICT OF INTEREST}

None.

\section{ACKNOWLEDGMENT}

None.

\section{REFERENCES}

[1] Ahmad A, Sastry MA (2004) Biological synthesis of triangular gold nanoprisms. Nat Mater 3: 482-488. 
Phytosynthesis and Characterization of Iron Nanocomposites by Irvingia Gabonensis (Ogbono) Aqueous and Ethanol Leaf Extracts

[2] Al-Gorair, Arej. S (2019). Treatment of wastewater from cationic dye using eco-friendly nanocomposite: Characterization, adsorption and kinetic studies. Egyptian Journal of Aquatic Research 45: 25-31

[3] Boparai, Hardiljeet K; Meera Joseph and Denis M O'Carroll (2011). Kinetics and thermodynamics of cadmium ion removal by adsorption onto nano zerovalent iron particles. Journal of hazardous materials 186(1):45865. DOI: 10.1016/j.jhazmat.2010.11.029

[4] Fang J, Haasl RJ, Dong Y, Lushington GH (2005) Discover protein sequence signatures from protein-protein interaction data. BMC Bioinformatics 6:277

[5] Frey NA, Sun M (2009) Shouheng materials, "Magnetic Nanoparticle for Information Storage Applications," no. Richter, pp: 33-68.

[6] Gole, A, C. Dash, V. Ramachandran, S.R. Sainkar, A.B. Mandale, M. Rao (2001). Pepsingold colloid conjugates: preparation, characterization and enzymatic activity. Langmuir, 17 (2001), pp. 1674-1679

[7] Gülçin, Ilhami; Zübeyr Huyut; Mahfuz Elmastaş and Hassan Y. Aboul-Enein (2010). Radical scavenging and antioxidant activity of tannic acid Arabian Journal of Chemistry 3(1):43-53 DOI: 10.1016/j.arabjc.2009.12.008

[8] Gupta AK, Gupta M (2005) Synthesis and surface engineering of iron oxide nanoparticles for biomedical applications. Biomaterials 26: 3995-4021.

[9] Gurunathan S, Kalishwaralal K, Vaidyanathan R, Venkataraman D, Pandian SR, (2009) Biosynthesis, purification and characterization of silver nanoparticles using Escherichia coli. Colloids Surf B Biointerfaces. 122: $155-160$

[10] Hedaginal B. R \& Taranath T. C. (2016). Phytosynthesis of Silver Nanoparticles by Thunbergia fragrans Roxb.and their Characterization. International Journal of Pharmaceutical Sciences Review and Research, 39(1), 54-58

[11] Hedaginal, B. R. \& Taranath, T. C. (2016). Phytosynthesis of Silver Nanoparticles by Thunbergia fragrans Roxb. And their Characterization. International Journal of Pharmaceutical Science Review and Research, 39(1) 5458

[12] Jagajjanani RK, Paria S (2013) Green synthesis of silver nanoparticles from aqueous Aegle marmelos leaf extract. Mater Res Bull 48: 628-634.

[13] Kannan RRR, Arumugam R, Ramya D, Manivannan K, Anantharaman P (2013) Green synthesis of silver nanoparticles using marine macroalga Chaetomorpha linum. Appl Nanosci 3:229-233

[14] Kim JS, Kuk E, Yu KN, Kim JH, Park SJ, Lee HJ, Kim SH, Park YK, Park YH, Huwang CY, Kim YK, Lee YS, Jeong DH, Cho MH (2007). Antimicrobial effects of silver nanoparticles. Nanomed. Nanotechnol. Biol. Med. 3: 95-101.

[15] Krishnaveni, K; A.S. Sakthi athithan; J.Jeyasundari; Y; Brightson Arul Jacob; D. Renuga (2018). Biosynthesis and characterisation of zinc doped iron oxide nanoparticles from pedalium murex and its new avenues in pharmacological applications Volume 13, Issue 6 Ver. I (Nov - Dec 2018), PP 67-74

[16] Laokul, P; V. Amornkitbamrung, S. Seraphin, and S. Maensiri, Characterization and magnetic properties of

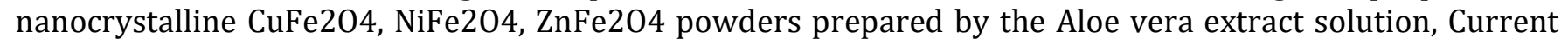
Applied Physics, 11(1), 2011, 101-108.

[17] Jebali, A., Ramezani, F., \& Kazemi, B. (2011). Biosynthesis of silver nanoparticles by Geotricum sp. Journal of Cluster Science, 22(2), 225-232.

[18] Mahdavi M, Namvar F, Ahmad MB, Mohamad R. Green biosynthesis and characterization of magnetic iron oxide $\left(\mathrm{Fe}_{3} \mathrm{O}_{4}\right)$ nanoparticles using seaweed (Sargassum muticum) aqueous extract. Molecules. 2013;18(5):5954-5964. Published 2013 May 21. doi:10.3390/molecules18055954

[19] Mandal, D., Bolander, M. E., Mukhopadhyay, D., Sarkar, G., \& Mukherjee, P. (2006). The use of microorganisms for the formation of metal nanoparticles and their application. Applied microbiology and biotechnology, 69(5), 485-492.

[20] Naik RR, Stringer SJ, Agarwal G, Jones S, Stone MO (2002) Biomimetic synthesis and patterning of silver nanoparticles. Nat Mater 1: 169-172

[21] Ojha MAK, Rout J, Behera S, Nayak PL (2013) Green synthesis and characterization of zero valent silver nanoparticles from the leaf extract of Datura. International Journal of Pharmaceutical Research \& Allied Sciences 2: 31-35.

[22] Raut RW, Kolekar NS, Lakkakula JR, Mendhulkar VD, Kashid SB (2010). Extracellular synthesis of silver nanoparticles using dried leaves of Pongamia pinnata (L) Pierre, Nano-Micro Lett. 2: 106-113.

[23] Salata OV (2004) Applications of nanoparticles in biology and medicine. J Nanobiotechnol 2: 3-8 
Ebong Sifon Emem, Adowei, Pereware, and Obuzor, Gloria Ukalina

[24] Shahwan, T., Abusirriah, S., Nairat, M., Boyac, E., Ero_glu, A.E., Scott, T.B., Hallam, K.R., 2011. Green synthesis of iron nanoparticles and their application as a Fenton-like catalyst for the degradation of aqueous cationic and anionic dyes. Chem. Eng. J. 172, 258-266.

[25] Sharma V, Sharma J (2017) Electron microscopy study of green synthesized zero valent Iron nanoparticle. Int J Eng Technol Sci Res 4.26-31

[26] Singh A, Jain D, Upadhyay MK, Khandelwal N, Verma HN (2010) Green synthesis of silver nanoparticles using Argemone mexicana leaf extract and evaluation of their antimicrobial activities. Digest J Nanomater Biostruct 5:483-489

[27] Varma, R. S. Greener approach to nanomaterials and their sustainable applications, Current Opinion in Chemical Engineering, 1(2), 2012, 123-128.

[28] Virkutyte, J., \& Varma, R. S. (2012). Environmentally friendly preparation of metal nanoparticles. In Sustainable Preparation of Metal Nanoparticles (pp. 7-33).

[29] Virkutyte, J., \& Varma, R. S. (2013a). Green synthesis of nanomaterials: environmental aspects. In Sustainable nanotechnology and the environment: advances and achievements (pp. 11-39). American Chemical Society.

[30] Virkutyte, J., \& Varma, R.S. (2013b). Environmentally Friendly Preparation of Metal Nanoparticles. In Sustainable Preparation of Metal Nanoparticles: Methods and Applications. The Royal Society of Chemistry. London, UK, pp. 7-33.

[31] Zahra Rezay Marand, study of magnetic and structural and optical properties of Zn doped Fe304 nanoparticles synthesised by coprecipitation method by biomedical application, Nanomedicine Journal, 1(4), 2014, 238-247.

[32] Zhang (2012) GY, Feng Y, Xu YY, Gao DZ, Sun YQ (2012) Controlled synthesis of mesoporous $\alpha$-Fe203 nanorods and visible light photocatalytic property. Mater Res Bull 47: 625-630 